\title{
Correction: Patient-reported outcome measures for use in clinical trials of SLE: a review
}

Izadi Z, Gandrup J, Katz PP, et al. Patient-reported outcome measures for use in clinical trials of SLE: a review. Lupus Sci Med 2018;5:e000279. doi: 10.1136/lupus-2018-000279

The authors noticed a potential data inconsistency in the published version. The 7 th statement needs to be updated in the first paragraph of the 'Lupus Impact Tracker' at page 10 .

The corrected information is: MIDs range from 2 to 4 for clinical deteriorations and an MID of -8.2 points has been reported for clinical improvements. ${ }^{83} 87$

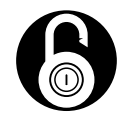

\section{OPEN ACCESS}

Open access This is an open access article distributed in accordance with the Creative Commons Attribution Non Commercial (CC BY-NC 4.0) license, which permits others to distribute, remix, adapt, build upon this work non-commercially, and license their derivative works on different terms, provided the original work is properly cited, appropriate credit is given, any changes made indicated, and the use is non-commercial. See: http://creativecommons.org/licenses/by-nc/4.0/

Lupus Sci Med 2018;5:e000279corr1. doi:10.1136/lupus-2018-000279corr1

A) Check for updates 